\title{
Security Challenges and Air Quality Management in India: Emissions Inventory and Forecasting Estimates
}

\author{
Haroon ur Rashid Khan ${ }^{1}$, Shujaat Abbas ${ }^{2}$, Muhammad Khalid Anser ${ }^{3} \mathbb{D}$, Abdelmohsen A. Nassani $^{4} \mathbb{D}^{\mathbb{D}}$, \\ Mohamed Haffar ${ }^{5}$ (D) and Khalid Zaman ${ }^{6, *}$
}

1 Faculty of Business, University of Wollongong in Dubai, Dubai 20183, United Arab Emirates; harunkhan1@gmail.com

2 Laboratory of International and Regional Economics, Graduate School of Economics and Management, Ural Federal University, Mira 19, 620002 Ekaterinburg, Russia; Shujaat.abbass@urfu.ru

3 School of Public Administration, Xi'an University of Architecture and Technology, Xi'an 710000, China; mkhalidrao@xauat.edu.cn

4 Department of Management, College of Business Administration, King Saud University, P.O. Box 71115, Riyadh 11587, Saudi Arabia; Nassani@ksu.edu.sa

5 Department of Management, Birmingham Business School, University of Birmingham, Birmingham B15 2TT, UK; m.haffar@bham.ac.uk

6 Department of Economics, University of Haripur, Khyber Pakhtunkhwa, Haripur 22620, Pakistan

* Correspondence: khalid.zaman@uoh.edu.pk

\section{check for}

updates

Citation: Khan, H.u.R.; Abbas, S.; Anser, M.K.; Nassani, A.A.; Haffar, M.; Zaman, K. Security Challenges and Air Quality Management in India: Emissions Inventory and Forecasting Estimates. Atmosphere 2021, 12, 1644. https://doi.org/ $10.3390 /$ atmos 12121644

Academic Editors: Yun Zhu, Jim Kelly, Jun Zhao, Jia Xing and Yuqiang Zhang

Received: 19 November 2021 Accepted: 2 December 2021 Published: 8 December 2021

Publisher's Note: MDPI stays neutral with regard to jurisdictional claims in published maps and institutional affiliations.

Copyright: (c) 2021 by the authors. Licensee MDPI, Basel, Switzerland. This article is an open access article distributed under the terms and conditions of the Creative Commons Attribution (CC BY) license (https:// creativecommons.org/licenses/by/ $4.0 /)$.
Abstract: The defense and peace literature have focused mainly on the military-growth nexus, with little attention paid to the environmental sustainability agenda, which is impacted by increased global arms transfers. The supply of lead-containing ammunition generates complex gas mixtures (including $\mathrm{CO}_{2}$ emissions) and particulates that harm the healthcare sustainability agenda. Based on the significance of the subject matter, the study uses the Indian economy as a case study, with a significant rate of arms transfers associated with higher carbon emissions. The study analyzed data from more than four decades, from 1975 to 2020. Data on arms imports, military personnel, and military expenditures are used to evaluate the 'ammunition emissions function'. It corresponds to the three research hypotheses, namely, the 'emissions-defense burden hypothesis' (arms transfers increase carbon emissions), the 'emissions-cleaner hypothesis' (arms transfers reduce carbon emissions), and the 'emissions-asymmetric hypothesis' (positive and negative shocks of arms transfers either support the 'defense burden hypothesis' or 'cleaner hypothesis'). The non-linear autoregressive distributed lag (NARDL) results confirmed the 'emissions-defense burden hypothesis' in the long run, as positive and negative shocks from arms imports increase carbon emissions. However, in the short run, positive arms imports increase carbon emissions while negative arms imports decrease carbon emissions. Furthermore, the findings supported the 'emissions-cleaner hypothesis' in the relationship between armed forces personnel and carbon emissions. The findings imply that the positive and negative shocks experienced by armed forces personnel reduce carbon emissions in the short and long run. Positive shocks to military spending support the 'emissions-defense burden hypothesis' in the short run; however, the results vanished when negative shocks to military spending supported the 'emissions-spillover hypothesis' (lowering military spending reduces carbon emissions and increases economic productivity) in the short and long run. The country's unsustainable economic activities are viewed as a negative factor contributing to long-term carbon emissions increases. The negative shocks of armed forces personnel and positive arms imports would almost certainly have a significant long-term impact on carbon emissions. As a result, the 'treadmill theory of destruction' has been confirmed in a country. The study concludes that lead-free ammunition and managing ammunition safety are beneficial to a country's environmental sustainability agenda.

Keywords: carbon emissions; arms transfers; military expenditures; armed forces personnel; NARDL; India 


\section{Introduction}

The United Nations sustainable development goal \#16 promotes global peace, stability, effective governance, and human rights. Growing armed conflicts and uncertainty adversely affect the economic development of many economies where the tension at the borders remains high, which damages the peaceful and inclusive society agenda [1]. The cost of carbon emissions increases health risk and damages the environmental agenda [2-4]. The growing tension of India with its neighboring countries in Asia, including Pakistan and China, is leading to an increase in its arms imports. Inadequate domestic arms production has caused an arms shortfall, increasing the country's dependency on fulfilling its arms by importing from abroad. India has emerged as a top five global arms importer, and is ranked second among the importers, surpassing Egypt, Australia, and China between 2016 and 2020, with an import share of 9.5\% globally [5]. In addition, India faces numerous environmental challenges from climate change to exacerbated air pollution levels in many megacities. Armaments supply and security issues are other challenges the country faces, causing more dangerous environmental hazards due to the supply of lead ammunition. Figure 1 shows the current status of military factors and carbon intensity levels from 1975 to 2020 .

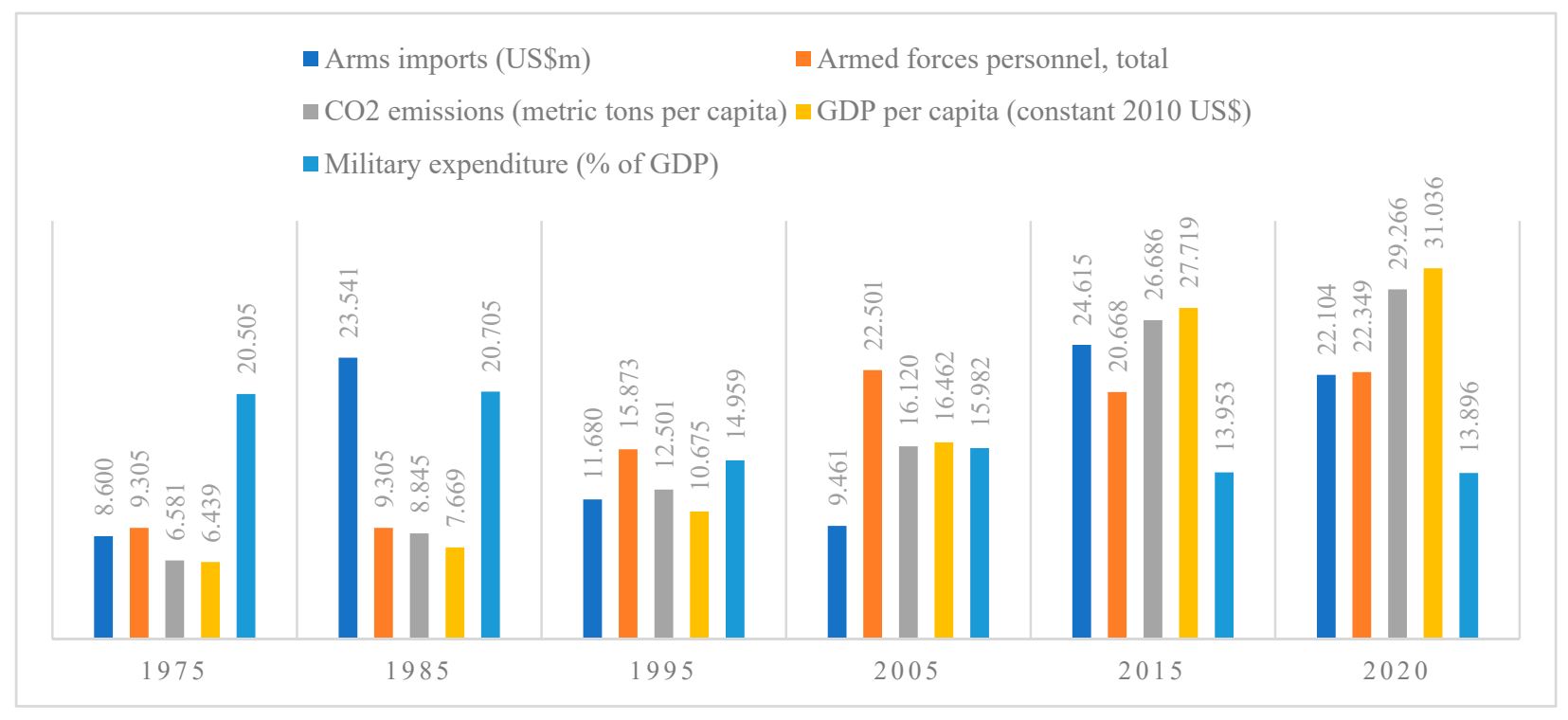

Figure 1. Trend analysis of arms transfers, carbon emissions, and India's economic growth (annual percentage growth). Source: World Bank [6].

Figure 1 shows that the annual percentage change in arms imports was 8.6\% in 1975 and reached $23.541 \%$ in 1985 , it then further increased to $24.615 \%$ in 2015 , after which it slightly decreased its share to $22.104 \%$ in 2020 . The armed forces personnel increased substantially at the same pace of arms imports during the stated periods. Its share increased from $9.305 \%$ in 1975 to $22.349 \%$ in 2020 . Carbon emissions outpaced its economic activities, which are consistently increasing over time. Its share increased from $6.581 \%$ in 1975 to reach $22.501 \%$ in 2005 , and then further increased to $29.266 \%$ in 2020 . The country's per capita increased along with an increase in carbon emissions and a decrease in military expenditure. The per capita income substantially increased from $6.439 \%$ in 1975 to $31.036 \%$ in 2020 . The annual change in military expenditures decreased from $20.505 \%$ to $13.896 \%$ between 1975 and 2020 [6]. The statistics show that the interrelationships during the studied period between the rise in carbon emissions, arms imports, and armed forces personnel found in the country, needs to be analyzed.

Earlier literature on defense and peace is mainly divided into four main aspects, i.e.,

(i) Literature on the Keynesian 'defense burden (KDB) hypothesis';

(ii) Reversal of the Keynesian hypothesis called spillover effect; 
(iii) Country-wide and regional assessment of the stated hypotheses; and

(iv) Rise and fall in a nation's output because of increasing military activity.

Alptekin and Levine [7] performed a meta-analysis on different aspects of military activities and growth-specific factors to evaluate the above-stated alternative hypotheses, and concluded that there was support for them in different economic and regional settings. The Keynesian 'defense burden hypothesis' (KDB) states that increased military activities compromise economic production, worsening economic outcomes. The crowding-out effect is inevitable because of increased military goods compared to consumer goods, such as spending on education, healthcare infrastructure, and consuming ecofriendly goods, which are largely neglected because of arms transfers worldwide. It increases regional tensions and security challenges, which hinder economic production at a large scale. Several studies have confirmed the hypothesis with different mediating factors regarding military expenditures and economic growth across countries. For instance, Luqman and Antonakakis [8] confirmed the KDB hypothesis in Pakistan by using human capital as a mediating factor, which is adversely affected by a country's increase in military expenditures compared to consumer goods. Human-induced developmental projects remain long-awaited in a queue because of inadequate social spending compromised by the increase in a country's defense budget. Çolak and Özkaya [9] used external debt as an influencing factor that mediated the relationship between military expenditures and growth-oriented activities in a panel of twelve transition economies. The results confirmed the KDB hypothesis, in that military expenditures were initially financed by domestic savings. Later on, it is financed by the external debt, which increases the crowding-out effect between military goods and consumer goods. Syed [10] considered a case study of three Asian countries, Pakistan, China, and India, and evaluated the Keynesian defense postulates given industrial productivity and military activities, which adversely affected the country's economic growth to support defense. Azam [11] confirmed the Keynesian defense postulate in a panel of 35 non-OECD countries and argued that countries need to minimize their defense budget to avoid the crowding-out situation, and to sustain economic activities through public spending.

The spillover effect increases a country's aggregate demand by lowering military expenditures. Economic progression plays a vital role in minimizing economic uncertainty and security issues through open dialogue and international peace talks. Strong institutions and peace stability help reduce Keynesian defense postulates and allow nations to move forward towards global prosperity. A large number of studies have confirmed the reversal of the Keynesian defense postulates to reduce socio-economic suffering [12-16]. Regional differences are likely to increase military tension between countries due to their endeavoring to win the arms race, and this create an imbalance of security issues, which need to be harmonized through strategic safety arms supply and by promoting global peace dialogues $[17,18]$. The non-linear relationships also hold in many instances in the earlier literature. The literature mostly confirms the rise and fall in economic activities due to increased militarization across countries $[19,20]$. Little literature on military factors and environmental degradation is available, which increases the urgency to work on the stated topic to find some conclusive policy inferences. For instance, Ullah et al. [15] confirmed that the militarization and non-militarization effects increase India's and Pakistan's economic growth at the cost of environmental degradation. It is essential for both countries to mutually understand the threat of environmental hazards and reduced military actions to improve their air quality level. Qayyum et al. [21] considered a case study of South Asian countries to assess the role of armed conflicts and increased military expenditures on ecological footprints. The results confirmed the same findings and argued that militarization activities and growing armed conflicts create a danger of increasing human pressure on land, leading to an increased carbon footprint in a region. Ahmed et al. [22] concluded that Pakistan's economy faces multifaceted socio-economic and environmental challenges, which have emerged through insecurity concerns in the country. Increased spending on military goods decreases economic growth and increases environmental damage, which 
need to be prevented through sustainable military action and the strengthening of the country's institutions. Ali et al. [23] argued that increased military activity decreases a country's economic growth while depleting many vital natural resources that need to be conserved for future generations. Based on the cited studies, the following research hypotheses need to be tested, i.e.,

Hypothesis 1 (H1). Asymmetric arms imports, likely increase carbon emissions, following the 'emissions-defense burden hypothesis'.

Hypothesis 2 (H2). Armed forces personnel are likely to follow the 'cleaner emissions hypothesis' undersigned by international treaties of ecological conservation.

Hypothesis 3 (H3). Military expenditures either follow the asymmetric 'emissions-defense' postulate or 'cleaner emissions hypothesis'.

Hypothesis 4 (H4). Continued economic growth is likely to increase carbon emissions on the premises of arms transfers in a country.

These hypotheses are implicitly linked with the earlier studies. For instance, Sohag et al. [24] argued that militarization adversely affected the green growth agenda that follows the Keynesian defense postulate. Wang et al. [25] concluded that continued economic growth complete with the carbon emissions, leads to high oil demand and influenced military expenditures, which in turn increase budget constraints and energy demand. Meulewaeter and Brunet [26] suggested that redirection of the military defense budget on consumer items helps to reduce climatic vulnerability and to enhance global human insecurity. Pathak [27] found that democracy and a country's affluence have a causal impact on increasing militarization. Democratic countries with low per capita income, and countries with low democratization with high per capita income, are interlinked by footprints of war that need to be sustained by environmental governance matters. Wang and $\mathrm{Su}$ [28] have suggested that governments and private entities should spend enormous amounts on improving military equipment to raise the prospect of a peaceful strategy and buildup harmony in cross-border relations, sustaining security in crude oil, greenfield energy investment, and reduction in arms conflicts.

The previous literature is rich in presenting various sustainable solutions to reduce carbon emissions, such as technological innovations [29], cleaner energy demand [30], natural resource management [31], and financial development [32], but it is limited to analyze the ammunition-emission nexus. The study has a novel contribution in the defense and peace literature in different aspects. First, the study evaluated different military factors related to carbon emissions to assess the country's efforts towards achieving a green developmental agenda through managing safe armaments supply. The earlier studies were limited to either the 'defense burden hypothesis' or spillover effects, which were powerless to explain the worldwide ecological reforms related to armaments supply [16,33]. Second, the study explored the asymmetric causation of arms imports, armed forces personnel, and military expenditures related to carbon emissions to assess the deviation of the military factors towards carbon emissions into positive and negative multiplier effects. The earlier studies worked on symmetric relationships between military expenditures and growthspecific factors while limiting work on a green developmental agenda [34-37]. Finally, the study assesses the inter-temporal forecasting relationship between military factors and carbon emissions, which was previously powerless to explain the relationships in a given country. Based on the study's novelty, the following research questions align with the policy matter, i.e., to what extent do arms imports increase carbon emissions and have a crowdingout effect on the country's aggregate demand? The question is essential, as high spending on military arms imports reduces spending on consumer items, and education-healthcare infrastructure has a crowding-out effect with the military goods; hence, it is important to verify the 'emissions-defense burden hypothesis'. The second question is: do armed 
forces personnel and military expenditures follow a 'cleaner emissions hypothesis'? The question is related to environmental protection. Increasing military expenditure and armed forces personnel worked under the strict guidelines of the arms treaty and its regulation to avoid an arms race and promote peace and sustainability agenda. Finally, do a nation's economic activities follow a sustainability path amid arms transfers? Through regional and international collaborations, the arms transfers should manage safety ammunition programs to support ecosystem and economic activities. The study's research objectives have been made in line with the stated discussion, i.e.,

(i) To examine the impact of arms imports on carbon emissions, following the 'emissionsdefense burden hypothesis'.

(ii) To analyze the role of military expenditures and armed forces personnel on carbon emissions, following the 'cleaner-emissions hypothesis' in a country, and

(iii) To investigate the nation's economic activities with regard to the arms transfers towards environmental protection agenda.

These objectives were evaluated based on non-linear ARDL estimates to assess the deviation in the military factors on carbon emissions, which helps to proposed sound policy inferences in the context of the Indian economy.

\section{Materials and Methods}

The study used three military factors, i.e., arms imports (denoted by AIMP, USD million), armed forces personnel (denoted by AFP, total numbers), and military expenditures (denoted by MEXP, \% of GDP), as regressors in the study that influenced carbon emissions. The study used $\mathrm{CO}_{2}$ emissions (denoted by $\mathrm{CO}_{2}$, metric tons per capita) as a response variable, while the GDP per capita (denoted by GDPPC, constant 2010 USD) served as a control variable of the study. The data was taken from World Bank [6] database, covering from 1975 to 2020 in the context of India. AFP data is available from 1989 to 2018, while carbon emission data is accessible from 1975 to 2018. The current year data of military expenditures is not available in the given database. The study filled the missing values by using their preceding and succeeding values of the same values of the respective variables to make a variables series consistent over time. The Indian economy has a high rate of arms transfers that jeopardize the natural environment and resource capital agenda. Hence, the stated variables are selected for empirical illustrations to offer potential sustainable military policies for supplying safe ammunition in a country.

\subsection{Theoretical Underpinning}

There is comparative literature on two different thematic areas, namely the Treadmill theory of production and Treadmill theory of destruction. The treadmill of production is discussed in C. Wright Mills' seminal work, which remains focused on two critical aspects, the first of which is 'politics', and the second is 'economics'. The expansion of economic production tends to deplete more natural resources, which has a negative impact on the future sustainability agenda of resource conservation. Militarism is the third component of Mills' theory that works in tandem with politics to achieve economic goals [38]. The treadmill theory of destruction arose as a result of capitalistic powers' inability to reduce ongoing military activities and expenditures, resulting in a crowding out effect between military and consumer goods, which justifies negative environmental externalities and significant deterioration of economic and natural resources [39]. The study was based on the 'treadmill of destruction/production (theory)' in the context of Indian economy. The study found the following irregularities in the Barro-type specification related to the military-growth nexus. Military expansion is associated, in many cases, with high carbon emissions and precious resource depletion, causing a deterioration in the country's economic growth, which ignores in the previous illustrations [7]. The 'ammunition-emissions function comprises the following possible postulates, i.e.,

(i) Emissions-defense postulate (Treadmill of destruction view) 
(ii) Emissions-cleaner postulate (Treadmill of production view), and

(iii) Extended version of the non-linear hypothesis, called asymmetric-emissions postulate

The stated ammunition-emissions postulates need a discussion to understand the new illustrations in military-growth nexus, i.e.,

(i) Emissions-Defense Postulate (Treadmill of destruction view): The emissions-defense postulate shows the crowding out a situation where government allocate a greater sum of money on military activities instead of consumer goods, including education and healthcare expenditures [40-42]. It is evident that military activities adversely affect the natural environment and precious natural resource capital, damaging human health and the natural environment with low spending on improving socio-economic infrastructure $[21,43,44]$. The greater supply of arms ammunition threatens regional security. It increased the risk of arms conflicts, which enforce increased military spending that adversely affects its affluence and natural resource capital [45].

(ii) Emissions-Cleaner Postulate (Treadmill of production view): The supply-side spillovers are associated with the of lowering military expenditures that increase spending on consumer goods to increase the country's aggregate demand [46-48]. The emissionscleaner postulate is designed in line with the stated spillovers effect. Lowering military expenditures positively impacts air quality indicators and improves the ecosystem, increasing the nation's aggregate demand for eco-friendly goods. Hence, the viability of preventing ecological damage and improving air quality levels can be attained by investing in military equipment and weapons that are designed in a way to reduce lead-free ammunition supply in a country, and

(iii) Asymmetric-Emissions Postulate: The non-linear relationship between military factors and economic growth is earlier accessed through doubling the military items to see the rise and fall in growth-specific factors in the earlier literature [19,38]. The study assessed the non-linear relationships asymmetrically to observe the positive and negative variations in the military factors on carbon emissions in a country to verify asymmetric-emissions postulate. The asymmetric-emission postulate can confirm either the 'emissions burden hypothesis' or 'emissions cleaner hypothesis' through absorbing positive and negative shocks about the specified military factors during the stated period.

Based on the ammunition-emissions function, the study used the following specification, i.e.,

$$
\begin{aligned}
& \mathrm{CO}_{2}=\delta_{0}+\delta_{1} A I M P+\delta_{2} A F P+\delta_{3} M E X P+\delta_{4} G D P P C+\varepsilon \\
& \therefore \frac{\partial\left(\mathrm{CO}_{2}\right)}{\partial(A I M P)}>0, \frac{\partial\left(\mathrm{CO}_{2}\right)}{\partial(A F P)}>0, \frac{\partial\left(\mathrm{CO}_{2}\right)}{\partial(M E X P)}>0, \frac{\partial\left(\mathrm{CO}_{2}\right)}{\partial(\text { GDPPC })}>0
\end{aligned}
$$

where $\mathrm{CO}_{2}$ shows carbon emissions, AIMP shows arms imports, AFP shows arms forces personnel, MEXP shows military expenditures, GDPPC shows GDP per capita, and $\varepsilon$ shows error term.

Equation (1) shows that arms imports, arms forces personnel, and military expenditures would likely cause environmental degradation due to military activities and weapon testing in operational sites. Further, the country's per capita income increases carbon emissions under cover of military expenditures.

\subsection{Econometric Framework}

The non-linear ARDL approach evaluates the stated objectives and hypotheses. Pesaran et al. [49] introduced different lag lengths in the exogenous and endogenous variables as regressors to obtain short- and long-term coefficient estimates. However, they do not transform the stated variables into possible positive and negative items limiting their implications into symmetric causation between them. This issue was addressed by Shin et al. [50] who decomposed a variables series into positive (+) and negative (-) shocks with the specific variable having different lag lengths, and observed their impact on the output variable. The remaining properties and assumptions remained similar to the conventional ARDL estimator, i.e., 
(i) NARDL estimator is equally applicable for the level variables, i.e., I(0) series, as ARDL estimator.

(ii) NARDL estimator gives decent inferences for the first differenced variables, i.e., I(1) series, as ARDL estimator.

(iii) NARDL is equally viable for $\mathrm{I}(0)$ and $\mathrm{I}(1)$ variables as ARDL estimator.

(iv) The error correction term can easily be computed in NARDL as an ARDL estimator.

(v) The NARDL is equally applicable for the finite sample data set as an ARDL estimator.

(vi) The same lag length criterion can be used in NARDL as an ARDL estimator.

(vii) The imposition of restrictions on short-term and long-term variables through Wald F-statistics can easily be applicable in NARDL as an ARDL estimator.

(viii) The long-run cointegrated relationship between the stated variables is equally validated in the NARDL system as an ARDL estimator.

(ix) The procedure of applying diagnostic testing for evaluating normality test, autocorrelation, heteroskedasticity, and Ramsey RESET test is the same in both the estimators.

(x) CUSUM and CUSUM square test for model stability is performed in both the test with a similar procedure.

A few differences exist in both the tests, i.e.,

(i) The ARDL estimator identifies the short- and long-run coefficients in linear terms, while NARDL coefficients are estimated in non-linear terms.

(ii) The variables are decomposed into positive and negative series to estimate asymmetric plots in the NARDL estimator while not being exercised in the ARDL estimator.

(iii) The NARDL specifications can be used in different cointegration processes, like Fully Modified OLS, Dynamic OLS, robust least squares estimator, etc., which gives asymmetric estimates. In contrast, the ARDL estimator cannot perform similarly to obtain dynamic inferences.

(iv) The asymmetric Granger causality estimates allow more insights to be made about causal inferences compared to the ARDL estimator.

(v) The innovation accounting matrix for evaluating forecast coefficient estimates can be used by positive and negative shocks of the candidate variables compared to the ARDL estimator over a time horizon.

The stated similarities and differences between the two estimators help to understand the nature of variables to perform different estimation procedures to achieve their stated study objectives. Equation (1) can be transformed in a general illustration of asymmetric regression to get insights about the estimator, i.e.,

$$
\mathrm{CO}_{2 t}=\delta_{0}+\delta_{1} A I M P_{t}^{+}+\delta_{2} A I M P_{t}^{-}+\delta_{3} A F P_{t}^{+}+\delta_{4} A F P_{t}^{-}+\delta_{5} M E X P_{t}^{+}+\delta_{6} M E X P_{t}^{-}+\delta_{7} G D P P C_{t}+\varepsilon_{t}
$$

where $A I M P^{+}, A I M P^{-}, A F P^{+}, A F P^{-}, M E X P^{+}$, and $M E X P^{-}$shows a positive and negative shock of the respective variables.

The study decomposed military factors, including AIMP, AFP, and MEXP, into two different series to trace out the positive $(+)$ and negative $(-)$ shocks in the given variables as follows:

$$
\begin{gathered}
A I M P_{t}^{+}=\sum_{j=1}^{t} \Delta A I M P_{j}^{+}=\sum_{j=1}^{t} \max \left(\Delta A I M P_{j}^{+}, 0\right) \\
A I M P_{t}^{-}=\sum_{j=1}^{t} \Delta A I M P_{j}^{-}=\sum_{j=1}^{t} \max \left(\triangle A I M P_{j}^{-}, 0\right) A F P_{t}^{+}=\sum_{j=1}^{t} \Delta A F P_{j}^{+}=\sum_{j=1}^{t} \max \left(\Delta A F P_{j}^{+}, 0\right) \\
A F P_{t}^{-}=\sum_{j=1}^{t} \Delta A F P_{j}^{-}=\sum_{j=1}^{t} \max \left(\Delta A F P_{j}^{-}, 0\right) \\
M E X P_{t}^{+}=\sum_{j=1}^{t} \Delta M E X P_{j}^{+}=\sum_{j=1}^{t} \max \left(\Delta M E X P_{j}^{+}, 0\right) \\
M E X P_{t}^{-}=\sum_{j=1}^{t} \Delta M E X P_{j}^{-}=\sum_{j=1}^{t} \max \left(\Delta M E X P_{j}^{-}, 0\right)
\end{gathered}
$$


Equation (3) further be transformed into the NARDL system equation, i.e.,

$$
\begin{aligned}
& \Delta C O_{2 t}=\eta_{0}+\sum_{k=0}^{p} \eta_{1} \Delta C O_{2 t-k}+\sum_{k=0}^{p} \eta_{2} \Delta A I M P_{t-k}^{+}+\sum_{k=0}^{p} \eta_{3} \Delta A I M P_{t-k}^{-}+\sum_{k=0}^{p} \eta_{4} \Delta A F P_{t-k}^{+}+\sum_{k=0}^{p} \eta_{5} \Delta A F P_{t-k}^{-} \\
& +\sum_{k=0}^{p} \eta_{6} \Delta M E X P_{t-k}^{+}+\sum_{k=0}^{p} \eta_{7} \Delta M E X P_{t-k}^{-}+\sum_{k=0}^{p} \eta_{8} \Delta G D P P C_{t-k}+\varsigma_{1} C O_{2 t-1}+\varsigma_{2} A I M P_{t-1}^{+}+\varsigma_{3} A I M P_{t-1}^{-} \\
& +\varsigma_{4} A F P_{t-1}^{+}+\varsigma_{5} A F P_{t-1}^{-}+\varsigma_{6} M E X P_{t-1}^{+}+\varsigma_{7} M E X P_{t-1}^{-}+\varsigma_{8} G D P P C_{t-1}+\mu_{t}
\end{aligned}
$$

The error correction term (ECT) can be further calculated by capturing the residual of the Equation (4) and taken as a regressor with its first lag to analyze the convergence of the short-run variables towards equilibrium with some speed of adjustment variable, i.e., ' $p$ ', which is as follows:

$$
\begin{aligned}
& \Delta \mathrm{CO}_{2 t}=\eta_{0}+\sum_{k=0}^{p} \eta_{1} \Delta C \mathrm{CO}_{2 t-k}+\sum_{k=0}^{p} \eta_{2} \Delta A I M P_{t-k}^{+}+\sum_{k=0}^{p} \eta_{3} \Delta A I M P_{t-k}^{-}+\sum_{k=0}^{p} \eta_{4} \Delta A F P_{t-k}^{+}+\sum_{k=0}^{p} \eta_{5} \Delta A F P_{t-k}^{-} \\
& +\sum_{k=0}^{p} \eta_{6} \Delta M E X P_{t-k}^{+}+\sum_{k=0}^{p} \eta_{7} \Delta M E X P_{t-k}^{-}+\sum_{k=0}^{p} \eta_{8} \Delta G D P P C_{t-k}+p E C T_{t-1}+\mu_{t}
\end{aligned}
$$

The Wald -F test is applied on Equation (4) on its long-run variables by imposing certain restrictions on the candidate variables to assess the cointegration relationship. The null and alternative hypotheses substantiate the long-run relationships of the following parameter estimates, i.e.,

$$
\begin{aligned}
& \mathrm{H}_{0}: \varsigma_{1}=\varsigma_{2}=\varsigma_{3}=\varsigma_{4}=\varsigma_{5}=\varsigma_{6}=\varsigma_{7}=\varsigma_{8}=0 \\
& \mathrm{H}_{\mathrm{A}}: \varsigma_{1} \neq \varsigma_{2} \neq \varsigma_{3} \neq \varsigma_{4} \neq \varsigma_{5} \neq \varsigma_{6} \neq \varsigma_{7} \neq \varsigma_{8} \neq 0
\end{aligned}
$$

The rejection of the null hypothesis can be checked through Wald F-statistics values that should fall in the upper Bound I(1) Narayan critical values at 5\% level. After analyzing different diagnostics testing and their confirmation about the residual series that should be normally distributed, free from autocorrelation and heteroskedasticity issues, the study applied Hatemi-J [51] asymmetric causality test for policy derives. Hetemi-J [52] argued that the cumulative sum of positive and negative shocks has different causal inferences. Hence, it is crucial to consider both the effects in the underlying system of causal inferences. Based on the suggested mechanism, the study shows a recursive solution of military factors in a system to form the possible variations in the variable series by using the VAR model of order $\mathrm{p}, \operatorname{VAR}(\mathrm{p})$, i.e.,

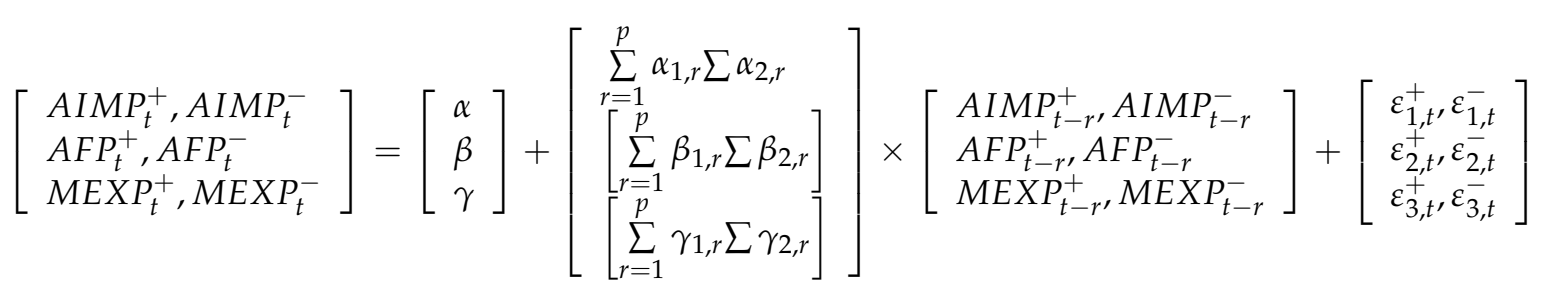

Based on Equation (6), the study specifies four possible alternative hypotheses for estimation, i.e.,

Postulate 1. Arms transfers Granger cause carbon emissions, not vice versa (one-way asymmetric causation).

Postulate 2. Carbon emissions Granger cause arms transfer but not vice versa (revere asymmetric causation).

Postulate 3. Arms transfers and carbon emissions move in the same direction (two-way asymmetric linkages), and

Postulate 4. Arms transfer and carbon emissions have no causal relationship, although correlated (neutrality hypothesis). 
The stated four postulates help to reach some conclusive findings that help for policy formulation in a country.

Sims [53] pioneered the evaluation of impulse response function (IRF) and variance decomposition analysis (VDA) in the VAR schematic fashion by moving the average method. It was augmented by Koop et al. [54] and Pesaran and Shin [55] to form generalized IRF and VDA to underlying the shocks in the system generated by the variables. HatemiJ [56] decomposed a variable series into positive and negative shocks assumed previously in the stated studies being constant. The positive and negative asymmetry allows for assessing the movement and magnitude of the respective variables towards the response variable over a time horizon. The same procedure is adopted in the study to evaluate the asymmetry innovation matrix for the next ten years' time period.

\section{Results}

Table 1 shows the descriptive statistics of the study. The lowest value of carbon emissions is 0.404 metric tons per capita, and the highest value is 1.799 , with a mean value of 0.937 metric tons per capita. The arms imports are USD $5.38 \times 10^{9}$ million with a mean value of USD $2.28 \times 10^{9}$ million. The total armed forces personnel in the country's data set from 1975 to 2020 was $3,047,000$ with an average of 2,028,878. The minimum and maximum values of military expenditures are $2.343 \%$ and $4.231 \%$, with an average value of $2.924 \%$ of GDP. The country's per capita income reached a maximum of USD 2152.216 with a mean value of USD 936.021. The data trends indicated that the country's economic growth and military expenditures increased along with an increase in carbon emissions that supported the ammunition emissions nexus in a studied period.

Table 1. Descriptive Statistics.

\begin{tabular}{lccccc}
\hline Methods & $\mathbf{C O}_{\mathbf{2}}$ & AIMP & AFP & MEXP & GDPPC \\
\hline Mean & 0.937 & $2.28 \times 10^{9}$ & $2,028,878$ & 2.924 & 936.021 \\
\hline Maximum & 1.799 & $5.38 \times 10^{9}$ & $3,047,000$ & 4.231 & 2152.216 \\
\hline Minimum & 0.404 & $7.37 \times 10^{8}$ & $1,260,000$ & 2.342 & 404.235 \\
\hline Std. Dev. & 0.447 & $1.09 \times 10^{9}$ & $713,071.9$ & 0.462 & 528.237 \\
\hline Skewness & 0.670 & 0.610 & 0.001 & 0.941 & 0.916 \\
\hline Kurtosis & 2.153 & 2.906 & 1.300 & 3.334 & 2.607 \\
\hline
\end{tabular}

Note: $\mathrm{CO}_{2}$ shows carbon emissions, AIMP shows arms imports, AFP shows armed forces personnel, MEXP shows military expenditures, and GDPPC shows GDP per capita.

Table 2 shows the estimates of the correlation matrix. The estimates show the positive correlation of arms imports, armed forces personnel, and continued economic growth with carbon emissions to verify the emissions-defense burden and crowd out the situation in country-level data. The military expenditures negatively correlated to the carbon emissions, verify the cleaner emissions hypothesis in a country. The continued economic growth is the critical factor causing more arms imports and increasing armed forces personnel $[57,58]$. Further, along with an increase in the country's economic growth, there is an increase in carbon emissions, arms imports, and armed forces personnel while a decrease in military expenditures during the stated period. The discussion confirmed the following statements, i.e.,

(i) The 'ammunition-emissions hypothesis' is supported by using arms imports and arms forces personnel concerning carbon emissions [59].

(ii) Unsustainable production and consumption are leading to increasing carbon emissions in a country [60].

(iii) Emissions-defense burden and crowding out situation is verified with important military factors and carbon emissions [61]. 
(iv) The 'cleaner-emissions hypothesis' is substantiated that increases a country's aggregate demand by lowering carbon emissions through eco-friendly arms transfers [62].

Table 2. Correlation Matrix.

\begin{tabular}{|c|c|c|c|c|c|}
\hline \multicolumn{2}{|c|}{ Correlation } & \multirow[b]{2}{*}{ AIMP } & \multirow[b]{2}{*}{ AFP } & \multirow[b]{2}{*}{ MEXP } & \multirow[b]{2}{*}{ GDPPC } \\
\hline Probability & $\mathrm{CO}_{2}$ & & & & \\
\hline $\mathrm{CO}_{2}$ & 1 & & & & \\
\hline AIMP & $\begin{array}{c}0.348 \\
(0.017)\end{array}$ & 1 & & & \\
\hline AFP & $\begin{array}{c}0.894 \\
(0.000)\end{array}$ & $\begin{array}{c}0.134 \\
(0.371)\end{array}$ & 1 & & \\
\hline MEXP & $\begin{array}{r}-0.725 \\
(0.000)\end{array}$ & $\begin{array}{c}0.165 \\
(0.273)\end{array}$ & $\begin{array}{l}-0.771 \\
(0.000)\end{array}$ & 1 & \\
\hline GDPPC & $\begin{array}{c}0.990 \\
(0.000)\end{array}$ & $\begin{array}{c}0.323 \\
(0.028)\end{array}$ & $\begin{array}{c}0.884 \\
(0.000)\end{array}$ & $\begin{array}{c}-0.710 \\
(0.000)\end{array}$ & 1 \\
\hline
\end{tabular}

Note: Small bracket shows probability value. $\mathrm{CO}_{2}$ shows carbon emissions, AIMP shows arms imports, AFP shows armed forces personnel, MEXP shows military expenditures, and GDPPC shows GDP per capita.

Table 3 shows the ADF unit root estimates. The studied variables are insignificant by using two different specifications, i.e., (i) variables are at a constant level and (ii) constant with the trend. The variability in the studied variables is dominating over a while, moving like a random walk hypothesis. The non-stationary variable's series becomes stationary by taking their first difference in both the suggested specifications, except GDPPC, which is significant at the first differenced 'constant with trend' apparatus. Hence, the variables, i.e., $\mathrm{CO}_{2}$, AIMP, AFP, MEXP, and GDPPC confirmed the first order of integrated variables, i.e., the I(1) series.

Table 3. ADF Unit Root Estimates.

\begin{tabular}{|c|c|c|c|c|c|}
\hline \multirow{2}{*}{ Variables } & \multicolumn{2}{|r|}{ Level } & \multicolumn{2}{|c|}{ First Difference } & \multirow{2}{*}{ Decision } \\
\hline & Constant & Constant and Trend & Constant & Constant and Trend & \\
\hline $\mathrm{CO}_{2}$ & $\begin{array}{c}2.496 \\
(1.000)\end{array}$ & $\begin{array}{l}-1.188 \\
(0.900)\end{array}$ & $\begin{array}{l}-5.302 \\
(0.000)\end{array}$ & $\begin{array}{l}-6.138 \\
(0.000)\end{array}$ & $\mathrm{I}(1)$ \\
\hline AIMP & $\begin{array}{l}-2.504 \\
(0.121)\end{array}$ & $\begin{array}{c}-2.494 \\
(0.329)\end{array}$ & $\begin{array}{l}-7.053 \\
(0.000)\end{array}$ & $\begin{array}{l}-6.967 \\
(0.000)\end{array}$ & $\mathrm{I}(1)$ \\
\hline AFP & $\begin{array}{c}-0.508 \\
(0.879)\end{array}$ & $\begin{array}{l}-2.499 \\
(0.327)\end{array}$ & $\begin{array}{l}-6.950 \\
(0.000)\end{array}$ & $\begin{array}{l}-6.884 \\
(0.000)\end{array}$ & $\mathrm{I}(1)$ \\
\hline MEXP & $\begin{array}{l}-1.886 \\
(0.335)\end{array}$ & $\begin{array}{l}-3.043 \\
(0.132)\end{array}$ & $\begin{array}{l}-4.980 \\
(0.000)\end{array}$ & $\begin{array}{l}-4.921 \\
(0.001)\end{array}$ & $\mathrm{I}(1)$ \\
\hline GDPPC & $\begin{array}{l}-1.936 \\
(0.313)\end{array}$ & $\begin{array}{l}-2.838 \\
(0.191)\end{array}$ & $\begin{array}{l}-1.763 \\
(0.393)\end{array}$ & $\begin{array}{c}-5.569^{\mathrm{a}} \\
(0.000)\end{array}$ & $\mathrm{I}(1)$ \\
\hline
\end{tabular}

Note: Small bracket shows probability value. $\mathrm{CO}_{2}$ shows carbon emissions, AIMP shows arms imports, AFP shows armed forces personnel, MEXP shows military expenditures, and GDPPC shows GDP per capita. ${ }^{a}$ show 'breakpoint unit root' estimates.

After identifying the variable's order of integration, the study decomposed AIMP, AFP, and MEXP into positive and negative series. Figure 2 shows the asymmetric plots of the stated variables. The positive multiplier of the factor AIMP is moving with the consistent pathway and remains within the $5 \%$ confidence interval. On the other hand, the negative 
shocks of AIMP are away from the confidence level; hence, it seems that the positive shocks of AIMP are likely to play a dominating role in ammunition-emissions function.
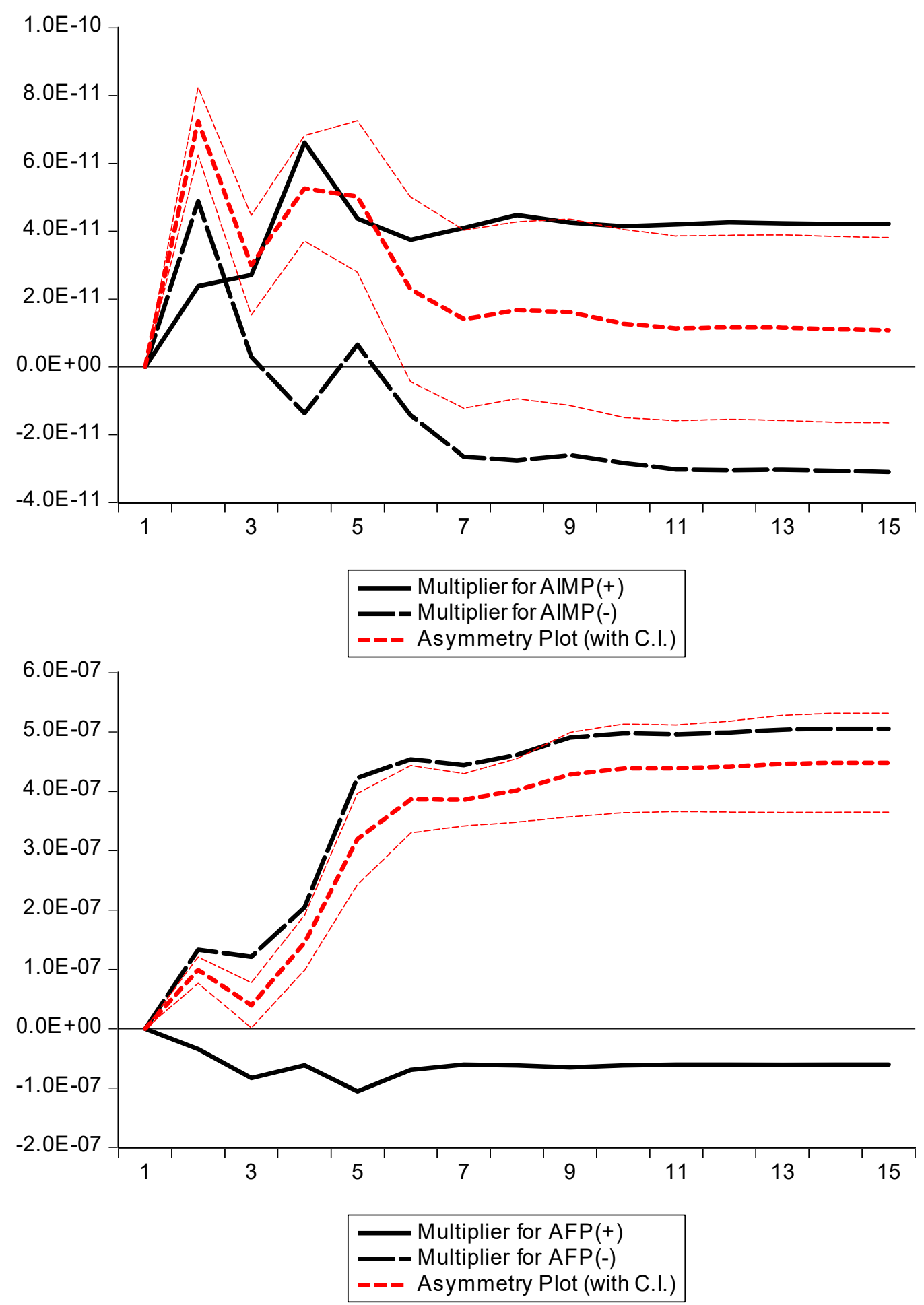

Figure 2. Cont. 


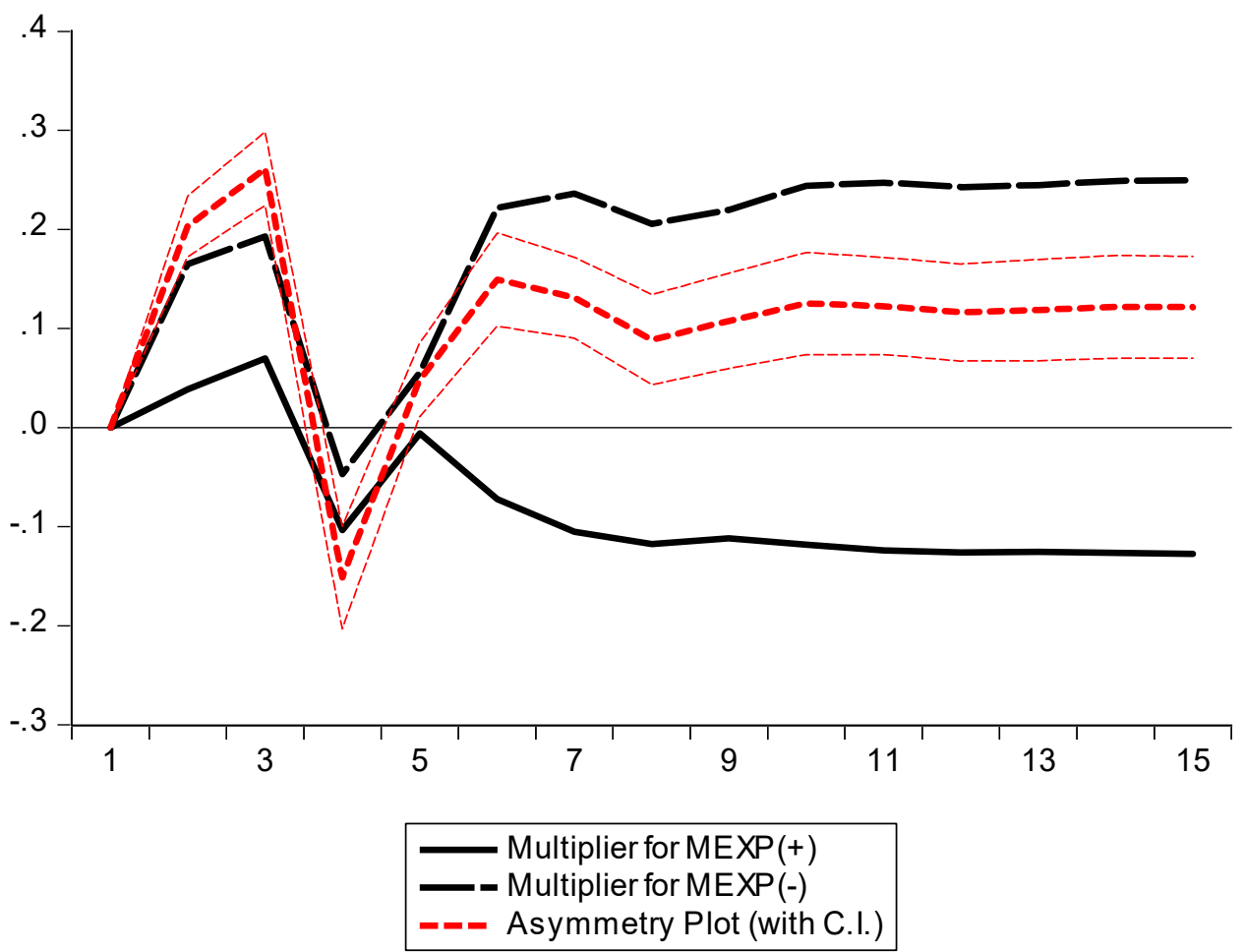

Figure 2. Asymmetric arms transfers plots. Source: author's estimate. Note: $\mathrm{AIMP}^{+}$and $\mathrm{AIMP}^{-}$shows positive and negative shocks in arms imports, $\mathrm{AFP}^{+}$and $\mathrm{AFP}^{-}$shows positive and negative shocks in armed forces personnel, and $\mathrm{MEXP}^{+}$and MEXP ${ }^{-}$shows positive and negative shocks in military expenditures.

Similar to the case of AFP, the $5 \%$ confidence interval falls within the positive and negative shocks of AFP. Hence, it examines caution while using the NARDL regression apparatus of parameter estimates. Finally, the positive and negative shocks of MEXP crossed a $5 \%$ level of significance in many instances. Hence, the impact would likely be more precise in the NARDL estimation procedure to give robust inferences on carbon emissions function. Table 4 shows the lag length selection criteria.

Table 4. Lag Length Selection Criterion.

\begin{tabular}{ccccccc}
\hline Lag & LogL & LR & FPE & AIC & SC & HQ \\
\hline 0 & -1779.682 & NA & $5.57 \times 10^{30}$ & 84.984 & 85.191 & 85.060 \\
1 & -1578.646 & 344.632 & $1.29 \times 10^{27 *}$ & 76.602 & $77.843^{*}$ & $77.057^{*}$ \\
2 & -1553.269 & 37.460 & $1.33 \times 10^{27}$ & 76.584 & 78.859 & 77.418 \\
3 & -1537.323 & 19.743 & $2.36 \times 10^{27}$ & 77.015 & 80.325 & 78.228 \\
4 & -1498.149 & $39.173 *$ & $1.61 \times 10^{27}$ & $76.340 *$ & 80.684 & 77.932 \\
\hline
\end{tabular}

Note: * indicates lag order selected by the criterion. LR: sequential modified LR test statistic (each test at $5 \%$ level). FPE: Final prediction error. AIC: Akaike information criterion. SC: Schwarz information criterion. HQ: Hannan-Quinn information criterion.

The statistics suggest that the lag length four of the regressors is desirable for using in NARDL estimation to obtain robust parameter inferences. The study considered the AIC criterion of lag length to obtain more insights about the previous shocks of the variables on the response variable. After deciding the optimal lag length of the variables, the study used NARDL estimates to obtain parameter estimates in the short- and long- run (see, Table 5). 
Table 5. NARDL short- and long run estimates.

\begin{tabular}{|c|c|c|c|c|}
\hline \multicolumn{5}{|c|}{$\begin{array}{l}\text { Dependent Variable: } \mathrm{CO}_{2 \mathrm{t}} \\
\text { Selected Model: }(4,3,4,4,4,4,4,4)\end{array}$} \\
\hline \multicolumn{5}{|c|}{ Cointegrating Form } \\
\hline Variable & Coefficient & Std. Error & t-Statistic & Prob. \\
\hline$\Delta\left(\mathrm{CO}_{2}\right)_{\mathrm{t}-1}$ & -0.0659 & 0.0585 & -1.1277 & 0.3765 \\
\hline$\Delta\left(\mathrm{CO}_{2}\right)_{\mathrm{t}-2}$ & -0.1628 & 0.0611 & -2.6642 & 0.1167 \\
\hline$\Delta\left(\mathrm{CO}_{2}\right)_{\mathrm{t}-3}$ & -0.0977 & 0.0535 & -1.8257 & 0.2094 \\
\hline$\Delta\left(\mathrm{AIMP} \_\mathrm{POS}\right)_{\mathrm{t}}$ & $2.37 \times 10^{-11}$ & $4.01 \times 10^{-12}$ & 5.8961 & 0.0276 \\
\hline$\Delta(\text { AIMP_POS })_{t-1}$ & $-2.26 \times 10^{-12}$ & $5.11 \times 10^{-12}$ & -0.4420 & 0.7017 \\
\hline$\Delta\left(\right.$ AIMP_POS $_{t-2}$ & $4.06 \times 10^{-11}$ & $4.15 \times 10^{-12}$ & 9.7826 & 0.0103 \\
\hline 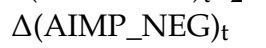 & $-4.89 \times 10^{-11}$ & $2.61 \times 10^{-12}$ & -18.713 & 0.0028 \\
\hline$\Delta(\text { AIMP_NEG })_{t-1}$ & $5.72 \times 10^{-11}$ & $1.68 \times 10^{-12}$ & 33.966 & 0.0009 \\
\hline$\Delta(\text { AIMP_NEG })_{t-2}$ & $1.29 \times 10^{-12}$ & $2.57 \times 10^{-12}$ & 0.5030 & 0.6649 \\
\hline$\Delta\left(\mathrm{AIMP} \_\mathrm{NEG}\right)_{\mathrm{t}-3}$ & $-1.64 \times 10^{-11}$ & $3.46 \times 10^{-12}$ & -4.7404 & 0.0417 \\
\hline$\Delta\left(\mathrm{AFP} \_\mathrm{POS}\right)_{\mathrm{t}}$ & $-3.44 \times 10^{-8}$ & $4.09 \times 10^{-9}$ & -8.4191 & 0.0138 \\
\hline$\Delta(\text { AFP_POS })_{t-1}$ & $-4.04 \times 10^{-8}$ & $4.72 \times 10^{-9}$ & -8.5668 & 0.0134 \\
\hline$\Delta\left(\mathrm{AFP}_{-} \mathrm{POS}\right)_{\mathrm{t}-2}$ & $2.94 \times 10^{-8}$ & $4.19 \times 10^{-9}$ & 7.0097 & 0.0198 \\
\hline$\Delta(\text { AFP_POS })_{t-3}$ & $-5.10 \times 10^{-8}$ & $6.42 \times 10^{-9}$ & -7.9320 & 0.0155 \\
\hline$\Delta\left(\mathrm{AFP} \_\mathrm{NEG}\right)_{\mathrm{t}}$ & $-1.34 \times 10^{-7}$ & $1.21 \times 10^{-8}$ & -11.044 & 0.0081 \\
\hline$\Delta\left(\mathrm{AFP} \_\mathrm{NEG}\right)_{\mathrm{t}-1}$ & $4.19 \times 10^{-8}$ & $1.03 \times 10^{-8}$ & 4.0559 & 0.0558 \\
\hline$\Delta\left(\mathrm{AFP} \_\mathrm{NEG}\right)_{\mathrm{t}-2}$ & $-9.94 \times 10^{-8}$ & $1.13 \times 10^{-8}$ & -8.8376 & 0.0126 \\
\hline$\Delta\left(\mathrm{AFP} \_\mathrm{NEG}\right)_{\mathrm{t}-3}$ & $-1.89 \times 10^{-7}$ & $2.17 \times 10^{-8}$ & -8.7021 & 0.0129 \\
\hline$\Delta\left(\mathrm{MEXP} \_\mathrm{POS}\right)_{\mathrm{t}}$ & 0.0384 & 0.0075 & 5.0722 & 0.0367 \\
\hline$\Delta\left(\mathrm{MEXP} \_\mathrm{POS}\right)_{\mathrm{t}-1}$ & 0.1764 & 0.0107 & 16.4135 & 0.0037 \\
\hline$\Delta\left(\mathrm{MEXP}_{-} \mathrm{POS}\right)_{\mathrm{t}-2}$ & -0.1381 & 0.0090 & -15.2831 & 0.0043 \\
\hline$\Delta\left(\mathrm{MEXP}_{-} \mathrm{POS}\right)_{\mathrm{t}-3}$ & 0.1108 & 0.0185 & 5.9889 & 0.0268 \\
\hline$\Delta\left(\mathrm{MEXP} \_\mathrm{NEG}\right)_{\mathrm{t}}$ & -0.1645 & 0.0153 & -10.7029 & 0.0086 \\
\hline$\Delta\left(\mathrm{MEXP} \_\mathrm{NEG}\right)_{\mathrm{t}-1}$ & -0.2306 & 0.0131 & -17.5103 & 0.0032 \\
\hline$\Delta\left(\mathrm{MEXP} \_\mathrm{NEG}\right)_{\mathrm{t}-2}$ & 0.1495 & 0.0096 & 15.5512 & 0.0041 \\
\hline$\Delta\left(\mathrm{MEXP} \_\mathrm{NEG}\right)_{\mathrm{t}-3}$ & 0.1018 & 0.0115 & 8.7789 & 0.0127 \\
\hline$\Delta(\mathrm{GDPPC})_{\mathrm{t}}$ & -0.0001 & 0.00004 & -2.5821 & 0.1229 \\
\hline$\Delta(\mathrm{GDPPC})_{\mathrm{t}-1}$ & -0.0004 & 0.00007 & -5.5871 & 0.0306 \\
\hline$\Delta(\mathrm{GDPPC})_{\mathrm{t}-2}$ & 0.00004 & 0.00004 & 1.2256 & 0.3451 \\
\hline$\Delta(\mathrm{GDPPC})_{\mathrm{t}-3}$ & 0.0004 & 0.00005 & 8.7882 & 0.0127 \\
\hline $\mathrm{ECT}_{\mathrm{t}-1}$ & -0.7037 & 0.0512 & -13.7324 & 0.0053 \\
\hline \multicolumn{5}{|c|}{ Long Run Coefficients } \\
\hline Variable & Coefficient & Std. Error & $\mathrm{t}$-Statistic & Prob. \\
\hline AIMP_POS & 0.000007 & 0.000002 & 3.731664 & 0.0649 \\
\hline AIMP_NEG & 0.000042 & 0.000009 & 4.719191 & 0.0491 \\
\hline AFP_POS & -0.000075 & 0.000012 & -6.072951 & 0.0261 \\
\hline AFP_NEG & -0.041776 & 0.004417 & -9.455991 & 0.0110 \\
\hline MEXP_POS & -0.125751 & 0.048754 & -2.579299 & 0.1232 \\
\hline MEXP_NEG & -0.247768 & 0.022630 & -10.948671 & 0.0082 \\
\hline GDPPC & 0.000244 & 0.000073 & 3.334640 & 0.0794 \\
\hline C & 0.201434 & 0.017825 & 11.300782 & 0.0077 \\
\hline
\end{tabular}

Note: $\mathrm{CO}_{2}$ shows carbon emissions, $\mathrm{AIMP}^{+}$and $\mathrm{AIMP}^{-}$shows positive and negative shocks in arms imports, $\mathrm{AFP}^{+}$and $\mathrm{AFP}^{-}$shows positive and negative shocks in armed forces personnel, MEXP+ and $\mathrm{MEXP}^{-}$shows positive and negative shocks in military expenditures, and GDPPC shows GDP per capita.

The NARDL estimates show that the positive shocks of arms imports increase carbon emissions in the short- and long run. However, divergent results were found with the negative shocks of arms imports. In the short run, arms imports' negative shocks decrease carbon emissions while increasing in the long run. Hence, it is clear that the positive and negative shocks of arms imports supported the 'emissions-defense burden hypothesis' in the long run. The result implies that along with an increase in arms imports, the crowding out situation is emerged because of the country's falling aggregate demand, 
leading to increase healthcare challenges because of increasing carbon emission. The earlier studies mainly supported the stated result and argued that arms transfers increase carbon emissions via asymmetric linkages between militarization and environmental degradation [63]. Ahmed et al. [64] concluded that economic growth played a vital role in reducing military arms transfers and carbon emissions and encouraged efficient energy investment to achieve green developmental objectives worldwide. Ferreira et al. [65] argued whether green ammunition lowers environmental challenges to reduce economic sufferings? The lifecycle assessment of warheads emphasized concentrating on production and assessment of ammunition technologies to lower environmental concerns. Further, the results show that positive and negative shocks of armed forces personnel support the 'cleaner emissions hypothesis', where increasing armed warriors is supposed to better protect the economy and decrease domestic and international conflicts, which increase aggregate demand of the country [66,67]. It is further helpful to initiate eco-friendly production and consumption in a country in safe hands $[68,69]$. In the short run, the positive shocks of military expenditures increase carbon emissions to substantiate the 'emissions-defense burden hypothesis'. However, in the long run, the negative shocks of military expenditures decrease carbon emissions and support the spillover effect of increasing economic productivity in a country. The results, supported by the earlier studies that argued that environmental pollution could be substantially decreased by increasing energy efficiency in the arms transfers [38], further escalate global income to spend an enormous amount on pollution control strategies [37]. Bradford and Stoner [66] claimed that wealthier nations who spend more defense budget allocation are indirectly associated with the increased carbon emissions, and that this needs to be revitalized through cleaner weapon technologies. Zandi et al. [70] argued that arms transfers increase carbon emissions due to a lack of governance reforms across countries. Fan et al. [71] found that arms transfers increase defense budget allocation, which create a crowding out of the situation, reducing government capacity to spend a significant amount on the country's health and wealth infrastructure. Sohag et al. [72] concluded that a green developmental agenda could be achieved using cleaner technologies and renewable energy demand, which is likely to change destructive ammunition war fields into green military bases.

\section{Discussion}

Table 6 shows the ARDL Bounds estimates to confirm the long-run cointegration between military factors and carbon emissions in a given country.

Table 6. NARDL Bounds Estimates.

\begin{tabular}{lcc}
\hline Test Statistic & Value & k \\
\hline F-statistic & 264.120 & 7 \\
\hline Significance & $\mathrm{I}(0)$ Bound & $\mathrm{I}(1)$ Bound \\
\hline $10 \%$ & 2.03 & 3.13 \\
\hline $5 \%$ & 2.32 & 3.5 \\
\hline $1 \%$ & 2.96 & 4.26 \\
\hline
\end{tabular}

The results show the higher Wald F-statistics value in the premises of six asymmetric military factors and one growth factor, which confirmed the $1 \%$ level of significance that fall in the upper bound I(1) critical value. Hence, the model is acceptable to follow a long-run relationship between the variables of the study. Table 7 shows the diagnostic estimates for ready reference. 
Table 7. Diagnostic Test Estimates.

\begin{tabular}{lcc}
\hline Methods & Statistics & Probability Value \\
\hline Jarque-Bera Test & 0.305 & 0.858 \\
\hline Autocorrelation LM (1) Test & 32.956 & 0.109 \\
\hline Heteroskedasticity Test & 0.475 & 0.864 \\
\hline Ramsey RESET Test & 0.154 & 0.902 \\
\hline
\end{tabular}

The estimates show that the Jarque-Bera normality test is insignificant at a $5 \%$ level of confidence. Hence, it confirmed that the error term is normally distributed. The autocorrelation test at first lag (while at second lag, it does not estimate the value) confirmed that the estimates are free from serial correlation issues. The insignificant estimates of heteroskedasticity confirmed that the error term has an equal variance during the study period. Finally, the model is functionally stable, as shown in the Ramsey RESET test. Figure 3 shows the asymmetric Granger causality estimates for ready reference.

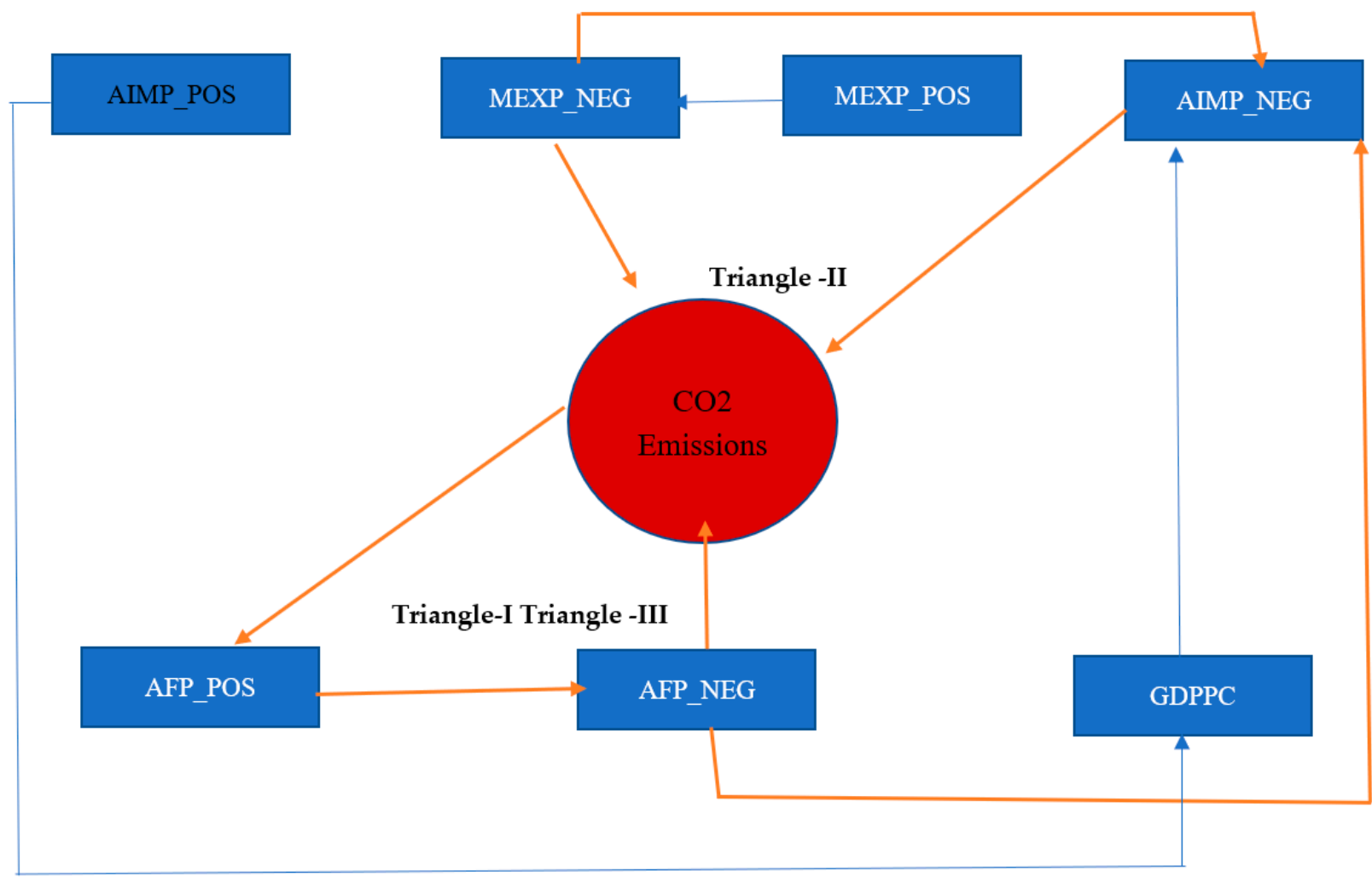

Figure 3. Granger casualty estimates. Note: $\mathrm{CO}_{2}$ shows carbon emissions, AIMP_POS and AIMP_NEG shows positive and negative shocks in arms imports, AFP_POS and AFP_NEG shows positive and negative shocks in armed forces personnel, MEXP_POS and MEXP_NEG shows positive and negative shocks in military expenditures, and GDPPC shows GDP per capita.

The asymmetric Granger causality estimates show three-dimensional triangles, denoted by triangles 1 to 3 . Triangle 1 shows that the negative shocks of armed forces personnel Granger cause carbon emissions. In contrast, carbon emissions Granger cause the positive shocks of armed forces personnel, making it a three-dimensional triangle, which implies that the relationship between them is asymmetric to verify the treadmill theory of destruction in a country. Triangle 2 shows the causal inferences between arms imports, military expenditure, and carbon emissions. The negative shocks of military expenditures Granger cause carbon emissions, while the negative shocks of arms im- 
ports Granger cause carbon emissions, making it a three-dimensional triangle to support 'ammunition-emissions hypothesis' in a country. Finally, triangle 3 shows the causation between armed forces personnel, arms imports, and carbon emissions. The negative shocks of armed forces personnel and arms imports Granger cause carbon emissions to support the 'emissions-defense hypothesis'. The causality inferences open a new avenue of policy thoughts to make military policies compatible with the green developmental agenda. Table 8 shows the asymmetric IRF of carbon emissions from 2002 to 2031.

Table 8. Asymmetric IRF estimates of $\mathrm{CO}_{2}$ emissions.

\begin{tabular}{ccccccccc}
\hline Period & CO $_{2}$ & AIMP_NEG & AIMP_POS & AFP_NEG & AFP_POS & MEXP_NEG & MEXP_POS & GDPPC \\
\hline 2022 & 0.023732 & 0 & 0 & 0 & 0 & 0 & 0 & 0 \\
2023 & 0.013883 & 0.009317 & 0.000499 & -0.008886 & 0.002094 & 0.001864 & 0.002737 & 0.009211 \\
2024 & 0.017386 & 0.004720 & 0.003433 & -0.014512 & 0.008155 & -0.002463 & 0.001287 & 0.012552 \\
2025 & 0.018795 & 0.004093 & 0.004918 & -0.021820 & 0.011603 & -0.000810 & 0.000622 & 0.010152 \\
2026 & 0.017703 & 0.006956 & 0.014305 & -0.024944 & 0.015274 & -0.001018 & 0.000545 & 0.006954 \\
2027 & 0.019114 & 0.009474 & 0.020195 & -0.026746 & 0.017221 & -0.001093 & -0.000159 & 0.001097 \\
2028 & 0.017660 & 0.011080 & 0.024554 & -0.025036 & 0.019989 & 0.000306 & 0.000676 & -0.003378 \\
2029 & 0.016434 & 0.011197 & 0.026787 & -0.019827 & 0.021142 & 0.001312 & 0.002671 & -0.003928 \\
2030 & 0.014491 & 0.009596 & 0.025409 & -0.013309 & 0.021146 & 0.001907 & 0.004474 & -0.001114 \\
2031 & 0.012272 & 0.007395 & 0.022921 & -0.006774 & 0.020808 & 0.001124 & 0.005128 & 0.003558 \\
\hline
\end{tabular}

Note: $\mathrm{CO}_{2}$ shows carbon emissions, AIMP_POS and AIMP_NEG shows positive and negative shocks in arms imports, AFP_POS and AFP_NEG shows positive and negative shocks in armed forces personnel, MEXP_POS and MEXP_NEG shows positive and negative shocks in military expenditures, and GDPPC shows GDP per capita.

The asymmetric IRF estimates suggest that the negative and positive shocks of arms imports and military expenditures would likely cause environmental damage in a country by increasing carbon emissions over time. The negative shocks of armed forces personnel will likely decrease carbon emissions, while a positive shock will increase carbon emissions for the next ten years. The country's economic growth is likely to increase carbon emissions from 2022 to 2027, while it is likely to decrease carbon emission afterwards till 2030, and then again to increase. The following results emerge with the forecasting estimates, i.e.,

(i) Arms imports and military expenditures will follow the 'treadmill theory of destruction'.

(ii) The 'cleaner-emissions hypothesis' is likely to become visible with negative shocks of armed forces personnel supporting the spillover hypothesis.

(iii) The country's affluence is likely to support cleaner emissions agenda in the wake of arms transfers in a country.

Table 9, in a similar line, estimated the asymmetric VDA of carbon emissions over a time horizon.

Table 9. Asymmetric VDA estimates of $\mathrm{CO}_{2}$ emissions.

\begin{tabular}{|c|c|c|c|c|c|c|c|c|c|}
\hline Period & S.E. & $\mathrm{CO}_{2}$ & AIMP_NEG & AIMP_POS & AFP_NEG & AFP_POS & MEXP_NEG & MEXP_POS & GDPPC \\
\hline 2022 & 0.023732 & 100 & 0 & 0 & 0 & 0 & 0 & 0 & 0 \\
\hline 2023 & 0.031971 & 73.95665 & 8.492226 & 0.024316 & 7.724729 & 0.428924 & 0.339911 & 0.732669 & 8.300572 \\
\hline 2024 & 0.042437 & 58.76132 & 6.057007 & 0.668277 & 16.07933 & 3.936670 & 0.529823 & 0.507842 & 13.45973 \\
\hline 2025 & 0.053943 & 48.50572 & 4.324451 & 1.244654 & 26.31257 & 7.063053 & 0.350441 & 0.327580 & 11.87153 \\
\hline 2026 & 0.066193 & 39.36708 & 3.976299 & 5.497217 & 31.67552 & 10.01515 & 0.256390 & 0.224342 & 8.988004 \\
\hline 2027 & 0.079113 & 33.39646 & 4.217709 & 10.36475 & 33.60423 & 11.74954 & 0.198560 & 0.157454 & 6.311298 \\
\hline 2028 & 0.091295 & 28.82066 & 4.640183 & 15.01709 & 32.75498 & 13.61686 & 0.150231 & 0.123721 & 4.876282 \\
\hline 2029 & 0.101548 & 25.91327 & 4.966278 & 19.09594 & 30.28613 & 15.34025 & 0.138119 & 0.169165 & 4.090853 \\
\hline 2030 & 0.109128 & 24.20174 & 5.073553 & 21.95672 & 27.71242 & 17.03816 & 0.150146 & 0.314543 & 3.552727 \\
\hline 2031 & 0.114711 & 23.04768 & 5.007302 & 23.86400 & 25.42921 & 18.71030 & 0.145486 & 0.484495 & 3.311518 \\
\hline
\end{tabular}

Note: $\mathrm{CO}_{2}$ shows carbon emissions, AIMP_POS and AIMP_NEG shows positive and negative shocks in arms imports, AFP_POS and AFP_NEG shows positive and negative shocks in armed forces personnel, MEXP_POS and MEXP_NEG shows positive and negative shocks in military expenditures, and GDPPC shows GDP per capita. 
The estimates show that the negative shocks of armed forces personnel and positive shocks of arms imports have a more significant variance than the carbon emissions of its shocks in the system. Further, positive shocks of armed forces personnel are likely to influence carbon emissions with a variance of $18.710 \%$, followed by the negative shocks of arms imports and the country's economic growth. The least influenced will be the negative shocks of military expenditures, which are likely to influence about $0.145 \%$ of carbon emissions from 2022 to 2031.

\section{Conclusions and Policy Implications}

Military activities consume more energy, increasing the risk of climate change around the world. The availability of lead-containing ammunition exacerbates the release of complex gases, such as carbon emissions, which pose health risks. The growing conflict between India and Pakistan and other Asian countries fuels the region's arms race, resulting in worsening economic and environmental conditions. The study examined asymmetric relationships between arms transfers and carbon emissions over a four-decade period. The findings show that positive shocks such as arms imports and military spending increase carbon emissions in the short run, supporting the asymmetric 'emissions-defense burden hypothesis'. On the other hand, the negative shocks of arms imports, armed forces personnel, and military expenditures reducing carbon emissions, confirms the asymmetric 'emissions-cleaner hypothesis'. The positive and negative shocks of arms imports increase carbon emissions in the long run. In contrast, positive-negative shocks to military personnel and negative military expenditures reduce carbon emissions, proving the 'asymmetric-emissions hypothesis'. The country's per capita income increases carbon emissions during the stated period. The causality estimates show the unidirectional relationship running from the negative shocks of military expenditures, arms imports, and armed forces personnel to having carbon emissions to substantiate the asymmetric 'military-led emissions' in a country. On the other hand, carbon emissions Granger cause the positive shocks of armed forces personnel to substantiate the 'emissions-asymmetric hypothesis'. The IRF estimates suggest that the positive shocks from arms imports, armed forces personnel, military expenditures, and negative shocks from arms imports would likely increase carbon emissions over the next ten years. On the other hand, the country's income and the negative shocks of armed forces personnel would almost certainly reduce carbon emissions over time. According to the VDA estimates, negative shocks from armed forces personnel and positive shocks from arms imports and arms forces personally would likely exert greater variance shocks to carbon emissions in subsequent years. Based on the critical findings, the following three-point policy agenda is proposed to reduce a country's military-led carbon emissions, i.e.,

(i) Excessive arms transfers confirm the 'emissions-defense burden hypothesis', which increases carbon emissions while deteriorating the country's green development agenda, which must be reduced by managing ammunition safety. The supply of lead-containing ammunition generates complex gases and particles, including carbon emissions, raising risks to human health. Lead-free ammunition reduces carbon content in the atmosphere, which aids in achieving the healthcare sustainability agenda. Aircraft, bulletproof vehicles, weaponry, radar systems, and military-used ships are among the items transferred. The following arms transfers should be environmentally friendly:

(a) The use of advanced cleaner technologies aids in the greening of aviation manufacturing.

(b) Arms transfer treaties aid in the reduction in illicit arms flows, thereby promoting the United Nations Sustainable Development Goal 16.

(c) To avoid negative environmental externalities, cleaner fuels should be used in armored vehicles and military ships.

(ii) Armed forces personnel and military spending confirm the 'cleaner emissions hypothesis', implying that the army in the field is equipped with green technology 
armaments to reduce carbon emissions through armament engineering. Furthermore, the defense burden is significantly reduces in order to move forward with the clean agenda. In the long run, the spillover effect helps increase aggregate demand for environmentally friendly goods due to increasing international pressure to conserve ecological resources. The country should reduce armed tensions to make progress toward the environmental sustainability agenda in the region.

(iii) The country's economic growth raises carbon emissions while increasing armament imports. Significant economic and environmental reforms are required for the country's consumption and production processes to be green and clean. A few corrective actions are suggested, such as,

(a) Armed conflicts should be resolved through dialogue and the peace movement, contributing to global prosperity.

(b) Arms regulations should be implemented in a region to reduce illicit arms flows.

(c) Armaments should be supplied following global environmental standards.

(d) Using renewable fuels instead of nonrenewable fuels in aviation, armored vehicles, and aircraft ships help to reduce carbon emissions.

(e) Significant reductions in military spending and arms transfers are likely to increase spending on education and healthcare infrastructure, which is considered one of the vital aspects of the United Nations sustainable development goals.

(f) Strict ecological reforms in the nations' consumption and goods production are critical to healthier development.

These critical considerations should be taken into account when developing a country's long-term military operations activities. The study focused on an essential aspect of the country's geopolitical armed conflict, which was thoroughly examined. Other aspects of the study, such as social-economical-environmental-energy-political indicators, can be evaluated further to make more accurate inferences about a country's treadmill theory of destruction.

Author Contributions: Conceptualization, H.u.R.K., S.A., M.K.A., K.Z., A.A.N. and M.H.; methodology, H.u.R.K., S.A., M.K.A., K.Z., A.A.N. and M.H.; software, H.u.R.K., S.A., K.Z., A.A.N. and M.H.; validation, H.u.R.K., S.A., A.A.N. and M.H.; formal analysis, H.u.R.K., S.A., M.K.A., K.Z., A.A.N. and M.H.; investigation, H.u.R.K., S.A., M.K.A. and M.H.; resources, A.A.N.; data curation, S.A. and K.Z.; writing-original draft preparation, H.u.R.K., S.A., M.K.A., K.Z., A.A.N. and M.H.; writing-review and editing, H.u.R.K., S.A., M.K.A., K.Z., A.A.N. and M.H.; visualization, S.A.; supervision, H.u.R.K and A.A.N.; project administration, S.A. and A.A.N.; funding acquisition, A.A.N. All authors have read and agreed to the published version of the manuscript.

Funding: Researchers Supporting Project number (RSP-2021/87), King Saud University, Riyadh, Saudi Arabia.

Institutional Review Board Statement: Not applicable.

Informed Consent Statement: Not applicable.

Data Availability Statement: The data is freely available at World Development Indicators published by World Bank (2021). Online available at: https:/ / databank.worldbank.org/source/worlddevelopment-indicators, accessed on 15 June 2021.

Acknowledgments: Researchers Supporting Project number (RSP-2021/87), King Saud University, Riyadh, Saudi Arabia.

Conflicts of Interest: The authors declare no conflict of interest. 


\section{References}

1. United Nations. Goal 16: Peace, Justice and Strong Institutions. 2015. Available online: https://sdgs.un.org/goals/goal16 (accessed on 13 September 2021).

2. Anser, M.K.; Abbas, S.; Nassani, A.A.; Haffar, M.; Zaman, K.; Abro, M.M.Q. Innovative Carbon Mitigation Techniques to Achieve Environmental Sustainability Agenda: Evidence from a Panel of 21 Selected R\&D Economies. Atmosphere 2021, $12,1514$. [CrossRef]

3. Fang, C.; Gao, H.; Li, Z.; Wang, J. Regional Air Pollutant Characteristics and Health Risk Assessment of Large Cities in Northeast China. Atmosphere 2021, 12, 1519. [CrossRef]

4. Yoda, Y.; Tamura, K.; Otani, N.; Hasunuma, H.; Nakayama, S.F.; Shima, M. Reduction in Indoor Airborne Endotoxin Concentration by the Use of Air Purifier and Its Relationship with Respiratory Health: A Randomized Crossover Intervention Study. Atmosphere 2021, 12, 1523. [CrossRef]

5. Aryan, J. The Evolving Landscape of India's Arms Trade. 2021. Available online: https://www.orfonline.org/expert-speak/theevolving-landscape-of-indias-arms-trade/ (accessed on 13 September 2021).

6. World Bank. World Development Indicators 2021; World Bank: Washington, DC, USA, 2021.

7. Alptekin, A.; Levine, P. Military expenditure and economic growth: A meta-analysis. Eur. J. Politial Econ. 2012, 28, 636-650. [CrossRef]

8. Luqman, M.; Antonakakis, N. Guns better than butter in Pakistan? The dilemma of military expenditure, human development, and economic growth. Technol. Forecast. Soc. Chang. 2021, 173, 121143. [CrossRef]

9. Çolak, O.; Özkaya, M.H. The Nexus between External Debts and Military Expenditures for the Selected Transition Economies: A Panel Threshold Regression Approach. Def. Peace Econ. 2020, 1-17. [CrossRef]

10. Syed, A. The asymmetric relationship between military expenditure, economic growth and industrial productivity: An empirical analysis of India, China and Pakistan via the NARDL approach. Rev. Finanz. Polit. Econ. 2021, 13, 77-97. [CrossRef]

11. Azam, M. Does military spending stifle economic growth? The empirical evidence from non-OECD countries. Heliyon 2020, 6 , e05853. [CrossRef] [PubMed]

12. Khalid, M.A.; Razaq, M.A.J.A. The Relationship between Military Expenditure and Economic Growth in Middle East and North Africa (Mena) Countries. J. Def. Resour. Manag. 2021, 12, 99-116.

13. Dimitraki, O.; Win, S. Military Expenditure Economic Growth Nexus in Jordan: An Application of ARDL Bound Test Analysis in the Presence of Breaks. Def. Peace Econ. 2020, 1-18. [CrossRef]

14. Meidutè-Kavaliauskienè, I.; Dudzevičiūtè, G.; Maknickienè, N. Military and demographic inter-linkages in the context of the Lithuanian sustainability. J. Bus. Econ. Manag. 2020, 21, 1508-1524. [CrossRef]

15. Ullah, A.; Zhao, X.; Kamal, M.A.; Zheng, J. Modeling the relationship between military spending and stock market development (a) symmetrically in China: An empirical analysis via the NARDL approach. Phys. A Stat. Mech. Appl. 2020, $554,124106$. [CrossRef]

16. Saba, C.S.; Ngepah, N. Convergence in military expenditure and economic growth in Africa and its regional economic communities: Evidence from a club clustering algorithm. Cogent Econ. Financ. 2020, 8, 1832344. [CrossRef]

17. Sahu, A.K. Heterogeneous security complex: A framework for the analysis of the China-India water conflict and South Asia. In Re-Imagining Border Studies in South Asia; Routledge: New Delhi, India, 2020; pp. 193-216.

18. Mastro, O.; Tarapore, A. Asymmetric but uneven: The China-India conventional military balance. In Routledge Handbook of China-India Relations; Tarapore, A., Bajpai, K., Ho, S., Miller, M.C., Eds.; Routledge: London, UK, 2020; pp. $235-247$.

19. Zaman, K.; Khan, H.U.R.; Islam, T.; Yousaf, S.U.; Nassani, A.A.; Khan, A.; Mustaffa, M.S.; Ahmad, J.; Hishan, S.S.; Aamir, A. Does higher military spending affect business regulatory and growth specific measures? Evidence from the group of seven (G-7) countries. Econ. Polit. 2019, 36, 323-348. [CrossRef]

20. Ul Ain, Q.; Rais, S.I.; Shah ST, H.; Zaman, K.; Ejaz, S.; Mansoor, A. Empirically testing Keynesian defense burden hypothesis, nonlinear hypothesis, and spillover hypothesis: Evidence from Asian countries. Theor. Appl. Econ. 2019, 26, 169-182.

21. Qayyum, U.; Anjum, S.; Sabir, S. Armed conflict, militarization and ecological footprint: Empirical evidence from South Asia. J. Clean. Prod. 2021, 281, 125299. [CrossRef]

22. Ahmed, Z.; Zafar, M.W.; Mansoor, S. Analyzing the linkage between military spending, economic growth, and ecological footprint in Pakistan: Evidence from cointegration and bootstrap causality. Environ. Sci. Pollut. Res. 2020, 27, 41551-41567. [CrossRef]

23. Ali, H.E. Natural Resource Rents and Military Expenditures in the Middle East and North Africa: A Long-run Perspective. Research Handbook on the Arms Trade. Edward Elgar Publishing, 2020. Available online: https:/ /www.elgaronline.com/view / edcoll/9781789900989/9781789900989.00016.xml/ (accessed on 13 September 2021).

24. Sohag, K.; Taşkın, F.D.; Malik, M.N. Green economic growth, cleaner energy and militarization: Evidence from Turkey. Resour. Policy 2019, 63, 101407. [CrossRef]

25. Wang, K.H.; Su, C.W.; Lobonţ, O.R.; Umar, M. Whether crude oil dependence and $\mathrm{CO}_{2}$ emissions influence military expenditure in net oil importing countries? Energ. Policy 2021, 153, 112281. [CrossRef]

26. Meulewaeter, C.; Brunet, P. Military spending and climate change. In Military Spending and Global Security; Routledge: London, UK, 2020; pp. 103-117. Available online: https:/ / www.taylorfrancis.com/chapters/edit/10.4324/9781003045823-8/militaryspending-climate-change-chlo\%C3\%A9-meulewaeter-pere-brunet (accessed on 14 September 2021). 
27. Pathak, S. Ecological footprints of war: An exploratory assessment of the long-term impact of violent conflicts on national biocapacity from 1962-2009. J. Environ. Stud. Sci. 2020, 10, 380-393. [CrossRef]

28. Wang, K.-H.; Su, C.-W. Does high crude oil dependence influence Chinese military expenditure decision-making? Energy Strat. Rev. 2021, 35, 100653. [CrossRef]

29. Ullah, S.; Ozturk, I.; Majeed, M.T.; Ahmad, W. Do technological innovations have symmetric or asymmetric effects on environmental quality? Evidence from Pakistan. J Clean Prod. 2021, 316, 128239. [CrossRef]

30. Alola, A.A.; Ozturk, I.; Bekun, F.V. Is clean energy prosperity and technological innovation rapidly mitigating sustainable energy-development deficit in selected sub-Saharan Africa? A myth or reality. Energy Policy 2021, 158, 112520. [CrossRef]

31. Abbasi, K.R.; Hussain, K.; Redulescu, M.; Ozturk, I. Does natural resources depletion and economic growth achieve the car-bon neutrality target of the UK? A way forward towards sustainable development. Resour. Policy 2021, 74, 102341. [CrossRef]

32. Khan, M.; Ozturk, I. Examining the direct and indirect effects of financial development on $\mathrm{CO}_{2}$ emissions for 88 developing countries. J. Environ. Manag. 2021, 293, 112812. [CrossRef] [PubMed]

33. Gómez-Trueba Santamaría, P.; Arahuetes García, A.; Curto González, T. A tale of five stories: Defence spending and economic growth in NATO' s countries. PLoS ONE 2021, 16, e0245260.

34. Nadeem, M.A.; Liu, Z.; Xu, Y.; Nawaz, K.; Malik, M.Y.; Younis, A. Impacts of terrorism, governance structure, military expenditures and infrastructures upon tourism: Empirical evidence from an emerging economy. Eurasian Bus. Rev. 2020, 10, 185-206. [CrossRef]

35. Sarwar, S.; Idrees, A.S. Impact of Military Expenditures on the Globalization Process: A Spatial Econometric Analysis for African Region. J. Asian Afr. Stud. 2021. [CrossRef]

36. Maher, M.; Zhao, Y. Do Political Instability and Military Expenditure Undermine Economic Growth in Egypt? Evidence from the ARDL Approach. Def. Peace Econ. 2021, 1-24. [CrossRef]

37. Ullah, S.; Andlib, Z.; Majeed, M.T.; Sohail, S.; Chishti, M.Z. Asymmetric effects of militarization on economic growth and environmental degradation: Fresh evidence from Pakistan and India. Environ. Sci. Pollut. Res. 2021, 28, 9484-9497. [CrossRef] [PubMed]

38. Gould, K.A.; Pellow, D.N.; Schnaiberg, A. Treadmill of Production: Injustice and Unsustainability in the Global Economy; Paradigm: Boulder, CO, USA; Routledge: New York, NY, USA, 2008.

39. Isiksal, A.Z. Testing the effect of sustainable energy and military expenses on environmental degradation: Evidence from the states with the highest military expenses. Environ. Sci. Pollut. Res. 2021, 28, 20487-20498. [CrossRef] [PubMed]

40. Aye, G.C.; Balcilar, M.; Dunne, J.P.; Gupta, R.; Van Eyden, R. Military expenditure, economic growth and structural instability: A case study of South Africa. Def. Peace Econ. 2014, 25, 619-633. [CrossRef]

41. Shahbaz, M.; Afza, T.; Shabbir, M.S. Does defence spending impede economic growth? cointegration and causality analysis for Pakistan. Def. Peace Econ. 2013, 24, 105-120. [CrossRef]

42. Hatemi-J, A.; Chang, T.; Chen, W.-Y.; Lin, F.-L.; Gupta, R. Asymmetric causality between military expenditures and economic growth in top six defense spenders. Qual. Quant. 2018, 52, 1193-1207. [CrossRef]

43. Mohammed, N.A.L. The Development Trap: Militarism, Environmental Degradation and Poverty in the South. In A World Divided; Routledge: London, UK, 2020; pp. 44-66.

44. Siacotos, M. Modern Military Weaponry and (un) Sustainable Treatment of the Environment. Commons Puget Sound J. Politics 2020, 1, 2. Available online: https://soundideas.pugetsound.edu/thecommons/vol1/iss1/2 (accessed on 15 September 2021).

45. Hooks, G.; Smith, C.L. Treadmills of production and destruction: Threats to the environment posed by militarism. Organ. Environ. 2005, 18, 19-37. [CrossRef]

46. Heo, U.; Ye, M. Defense Spending and Economic Growth around the Globe: The Direct and Indirect Link. Int. Interact. 2016, 42, 774-796. [CrossRef]

47. Ram, R. Conceptual Linkages between Defense Spending and Economic Growth and Development: A Selective Review. Defense Spending and Economic Growth; Routledge: London, UK, 2019. Available online: https://www.taylorfrancis.com/chapters/edit/10.4324/97 80429040863-2/conceptual-linkages-defense-spending-economic-growth-development-selective-review-rati-ram (accessed on 15 September 2021).

48. Topal, M.H.; Unver, M.; Türedi, S. The military expenditures and economic growth nexus: Panel bootstrap granger causality evidence from NATO countries. Panoeconomicus 2021, 2. [CrossRef]

49. Pesaran, M.H.; Shin, Y.; Smith, R.J. Bounds testing approaches to the analysis of level relationships. J. Appl. Econom. 2001, 16, 289-326. [CrossRef]

50. Shin, Y.; Yu, B.; Greenwood-Nimmo, M. Modelling Asymmetric Cointegration and Dynamic Multipliers in a Nonlinear ARDL Framework. In The Festschrift in Honor of Peter Schmidt: Econometric Methods and Applications; Horrace, W., Sickles, R., Eds.; Springer: New York, NY, USA, 2014; pp. 281-314. [CrossRef]

51. Hatemi-J, A. Asymmetric causality tests with an application. Empir. Econ. 2012, 43, 447-456. [CrossRef]

52. Hatemi-J, A.; El-Khatib, Y. An extension of the asymmetric causality tests for dealing with deterministic trend components. Appl. Econ. 2016, 48, 4033-4041. [CrossRef]

53. Sims, C.A. Macroeconomics and Reality. J. Econometr. Soc. 1980, 48, 1-48. [CrossRef]

54. Koop, G.; Pesaran, M.; Potter, S.M. Impulse response analysis in nonlinear multivariate models. J. Econ. 1996, $74,119-147$. [CrossRef] 
55. Pesaran, H.; Shin, Y. Generalized impulse response analysis in linear multivariate models. Econ. Lett. 1998, 58, 17-29. [CrossRef]

56. Hatemi, J.A. Asymmetric Generalized Impulse Responses and Variance Decompositions with an Application. 2011. Available online: https://mpra.ub.uni-muenchen.de/31700/1/MPRA_paper_31700.pdf (accessed on 15 September 2021).

57. Greiner, P.T.; McGee, J.A. Divergent Pathways on the Road to Sustainability: A Multilevel Model of the Effects of Geopolitical Power on the Relationship between Economic Growth and Environmental Quality. Socius Sociol. Res. Dyn. World 2018, 4, 1-15. [CrossRef]

58. Jorgenson, A.K.; Fiske, S.; Hubacek, K.; Li, J.; McGovern, T.; Rick, T.; Schor, J.B.; Solecki, W.; York, R.; Zycherman, A. Social science perspectives on drivers of and responses to global climate change. Wiley Interdiscip. Rev. Clim. Chang. 2019, 10, e554. [CrossRef]

59. Hooks, G.; Smith, C.L. The Treadmill of Destruction: National Sacrifice Areas and Native Americans. Am. Sociol. Rev. 2004, 69, 558-575. [CrossRef]

60. Jorgenson, A.; Clark, B. Are the Economy and the Environment Decoupling? A Comparative International Study, 1960-2005. Am. J. Sociol. 2012, 118, 1-44. [CrossRef]

61. Hooks, G.; Smith, C.L. The treadmill of destruction goes global: Anticipating the environmental impact of militarism in the 21st century. In The Marketing of War in the Age of Neo-Militarism; Gouliamos, K., Kassimeris, C., Eds.; Routledge: London, UK, 2013; pp. 60-83.

62. Jorgenson, A.; Clark, B.; Kentor, J. Militarization and the Environment: A Panel Study of Carbon Dioxide Emissions and the Ecological Footprints of Nations, 1970-2000. Glob. Environ. Polit. 2010, 10, 7-29. [CrossRef]

63. Smith, C.L.; Lengefeld, M.R. The Environmental Consequences of Asymmetric War: A Panel Study of Militarism and Carbon Emissions, 2000-2010. Armed. Forces Soc. 2020, 46, 214-237. [CrossRef]

64. Ahmed, S.; Alam, K.; Rashid, A.; Gow, J. Militarisation, energy consumption, $\mathrm{CO}_{2}$ emissions and economic growth in Myanmar. Def. Peace Econ. 2020, 31, 615-641. [CrossRef]

65. Ferreira, C.; Ribeiro, J.; Almada, S.; Freire, F. Environmental Assessment of Ammunition: The Importance of a Life-Cycle Approach. Propellants Explos. Pyrotech. 2017, 42, 44-53. [CrossRef]

66. Bradford, J.H.; Stoner, A. The Treadmill of Destruction in Comparative Perspective: A Panel Study of Military Spending and Carbon Emissions, 1960-2014. J. World-Syst. Res. 2017, 23, 298-325. [CrossRef]

67. Clark, B.; Jorgenson, A.K. The Treadmill of Destruction and the Environmental Impacts of Militaries1. Sociol. Compass 2012, 6, 557-569. [CrossRef]

68. Clark, B.; Jorgenson, A.K.; Kentor, J. Militarization and energy consumption: A test of treadmill of destruction theory in comparative perspective. Int. J. Sociol. 2010, 40, 23-43. [CrossRef]

69. Gould, K.A. The Ecological Costs of Militarization. Peace Rev. 2007, 19, 331-334. [CrossRef]

70. Zandi, G.; Haseeb, M.; Abidin IS, Z. The impact of democracy, corruption and military expenditure on environmental degradation: Evidence from top six Asean countries. Humanit. Soc. Sci. Rev. 2019, 7, 333-340. [CrossRef]

71. Fan, H.; Liu, W.; Coyte, P.C. Do Military Expenditures Crowd-out Health Expenditures? Evidence from around the World, 2000-2013. Def. Peace Econ. 2018, 29, 766-779. [CrossRef]

72. Sohag, K.; Husain, S.; Hammoudeh, S.; Omar, N. Innovation, militarization, and renewable energy and green growth in OECD countries. Environ. Sci. Pollut. Res. 2021, 28, 36004-36017. [CrossRef] 